\title{
Malachite green dye behaviors in the presence of biosorbents from maize (Zea mays L.), their Fe-Cu nanoparticles composites and $\mathrm{Fe}-\mathrm{Cu}$ nanoparticles.
}

\author{
E.J. Lara-Vásquez ${ }^{\mathrm{a}}$, M. Solache-Ríos ${ }^{\mathrm{b}}$, E. Gutiérrez-Segura ${ }^{\mathrm{a}, *}$ \\ ${ }^{a}$ Facultad de Química, Universidad Autónoma del Estado de México, Paseo Colón y Tollocan s/n, C.P. 50000 Toluca, Estado de México, Mexico \\ ${ }^{\mathrm{b}}$ Departamento de Química, Instituto Nacional de Investigaciones Nucleares, A. P. 18-1027, Col. Escandón, Delegación Miguel Hidalgo, C.P. 11801 México, D. F., \\ Mexico
}

\section{A R T I C L E I N F O}

Article history:

Received 1 December 2015

Received in revised form 29 January 2016

Accepted 2 February 2016

Available online 4 February 2016

\section{Keywords:}

Adsorption

Malachite green

Maize

Composite

Fe-Cu nanoparticles

\begin{abstract}
A B S T R A C T
The sorption behaviors of biosorbent based on maize (Zea mays, ZM) cane (bagasse and stalk), their composites (ZM/Fe-Cu nanoparticles) and $\mathrm{Fe}-\mathrm{Cu}$ nanoparticles for malachite green from aqueous solutions were investigated in this work. Adsorbents were characterized using BET, infrared spectroscopy, X-ray diffraction, SEM-EDS, and Fe-Cu nanoparticles were characterized by TEM. The study of the sorption kinetics indicates that the adsorption on malachite green by stalk and their composite follows second-order kinetics and nanoparticles and bagasse and their composite follow the pseudo-second order model. The malachite green adsorption by $\mathrm{ZM} / \mathrm{Fe}-\mathrm{Cu}$ composites were faster than natural materials and only showed two phases in the intraparticle diffusion model, probably due to the minor internal diffusion resistance. The adsorption isotherms experimental data were analyzed by the Langmuir, Freundlich and Langmuir-Freundlich models and the equilibrium data was well described by the Langmuir-Freundlich isotherm model. The adsorption was more favorable at basic $\mathrm{pH}$. The $\mathrm{OH}-$ groups were proportional to dye adsorption capacities. Results showed that composites (ZM/Fe-Cu nanoparticles) and $\mathrm{Fe}-\mathrm{Cu}$ nanoparticles possessed good adsorption abilities to malachite green.
\end{abstract}

(c) 2016 Elsevier Ltd. All rights reserved.

\section{Introduction}

Industrial dyeing and finishing processes generate large amounts of colored wastewater, which are discharged into natural streams with undesirable consequences to the environment and human health [1]. Malachite green (MG) dye is most commonly used for dyeing cotton, silk, paper, leather and also in manufacturing of paints and printing inks. Malachite green is widely used in distilleries and also considered as an antiseptic for external applications on wounds and ulcers, however, its oral consumption is toxic, hazardous and carcinogenic [2]. Malachite green when discharged into streams affects aquatic life and causes detrimental effects in liver, gill, kidney, intestine, gonads and pituitary gonadotropic cells. Therefore, it would be desirable to remove it from wastewaters before they are discharged [3].

The conventional treatments of dyed wastewater include chemical coagulation, biological, ozonation, advanced oxidation processes; filtration, ion exchange and adsorption by activated

\footnotetext{
* Corresponding author.

E-mail address: eegutierrezs@uaemex.mx (E. Gutiérrez-Segura).
}

carbon, each of these methods have inherent limitations. Yagub, et al. reported the advantages and disadvantages of different dye removal methods [4]. Adsorption has been shown to be the most promising process for all non-biodegradable organics for the removal from aqueous streams, activated carbons is the most common adsorbent for this purpose due to its effectiveness and versatility, but it is an expensive sorbent.

Low-cost adsorbents are materials that generally require little processing and are abundant in nature, or are by-products or waste materials from other processes [5]. Agricultural by-products are available in large quantities and constitute one of the most abundant renewable resources in the world [6]. The lignin cellulosic biomasses behave as good effective adsorbents; however they have low sorption efficiencies, therefore structural modifications onto the biosorbents have been performed in order to enhance their binding capacities, selectivity and environmental stability in terms of their reusability [7,8]. Many researchers have reported the feasibility of using various low cost adsorbents and non-conventional sorbentes to remove malachite green from aqueous solutions, such as bivalve shell-treated Zea mays $L$. (maize) husk leaf [9], pine wood [10], clay [11], carbon from spent tea 
leaves [12], walnut shell [13], sodium alginate-coated $\mathrm{Fe}_{3} \mathrm{O}_{4}$ nanoparticles [14].

Maize particularly is a widely cropped annual cereal that grows rapidly, produces extensive fibrous root system, withstands adverse conditions, and produces abundant seeds. Various investigators have modified the nature biopolymers with specific functional groups to remove specific pollutants and to improve their adsorption abilities and efficiencies, such as modifications with carboxyl groups [15].

Recently, it has been found that $\mathrm{Fe} / \mathrm{Cu}$ bimetallic particles prepared by deposition of $\mathrm{Cu}^{\circ}$ on the surface of $\mathrm{Fe}^{\circ}$ and chemical reduction method, can enhance rates of pollutants reduction remarkably due to the high potential difference $(0.78 \mathrm{~V})$ between $\mathrm{Cu}$ and $\mathrm{Fe}[16]$. Some studies suggested that $\mathrm{Fe} / \mathrm{Cu}$ bimetallic particles could be proposed as a cost-effective pretreatment materials for the toxic organic wastewater. The mechanism for organic compounds removal using $\mathrm{Fe} / \mathrm{Cu}$ bimetallic particles in absence of dissolved oxygen (DO) is that the $\mathrm{Cu}$ located on the iron surface can accelerate the corrosion of Fe and the generation of $\left[\mathrm{H}^{+}\right]$. In contrast, under oxic conditions, DO can enhance the generation of hydroxyl ions and improve the formation of iron hydroxides. It has been found that iron hydroxide can easily adsorb organic molecules containing electron-donating groups, so plenty of newborn organic compounds in the aqueous solution was adsorbed and co-precipitated with iron hydroxides. Several studies have indicated that Fe corrosion in the presence of air can generate hydrogen peroxide onto aqueous system. The hydrogen peroxide can react with $\mathrm{Fe}^{2+}$ (Fenton-like reaction) and produce strong oxidants such as hydroxyl radical $\mathrm{OH}^{\bullet}$, the presence of $\mathrm{Cu}$ could enhance the corrosion of Fe to generate ferrous iron so that the oxidation could be improved [17].

In this work, the components of maize cane (bagasse and stalk) were modified with nanoparticles $\mathrm{Fe}-\mathrm{Cu}$ for the removal of malachite green from aqueous solutions. The adsorption performance parameters (i.e., contact time, concentration, temperature, $\mathrm{pH}$ and mass effect) and the mechanism of the adsorption process were determined.

\section{Materials and methods}

\subsection{Materials}

Malachite green (Basic Green 4, C.I.: 42,000, molecular formula: $\mathrm{C}_{23} \mathrm{H}_{25} \mathrm{~N}_{2} \mathrm{Cl}$, molecular wt.: $365 \mathrm{~g} / \mathrm{mol}, \lambda_{\text {max }}: 620 \mathrm{~nm}$ ), was purchased from Hycel, Mexico, and its chemical structure is shown in Fig. 1. Dye solution was prepared by dissolving an appropriate amount of dye in distilled water. The concentrations of the samples were determined by using a standard calibration plot that showed a linear variation up to $100 \mathrm{mg} / \mathrm{L}$ concentration.

The maize (Zea mays, ZM) stalk from Tenancingo, Mexico was dried. Bagasse material was separated from the maize stalk before being ground; the particle size of both materials used in this work

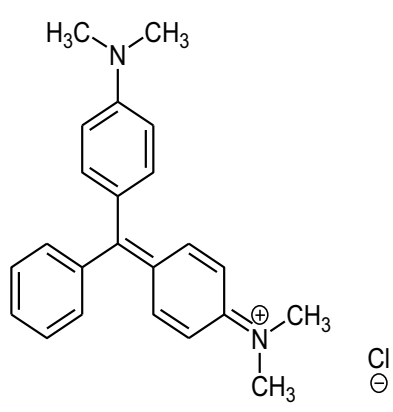

Fig. 1. Structure of malachite green dye. was between $0.84 \mathrm{~mm}$ and $0.42 \mathrm{~mm}$. Materials were washed with distilled water several times to remove the dust and finally dried in an oven for 3 days at $30^{\circ} \mathrm{C}$. The adsorbent materials were soaked for $24 \mathrm{~h}$ in a $0.2 \%$ formaldehyde solution and they were washed with distilled water and dried at $60^{\circ} \mathrm{C}$ for $24 \mathrm{~h}$. The synthesis of Fe$\mathrm{Cu}$ nanoparticles and $\mathrm{ZM} / \mathrm{Fe}-\mathrm{Cu}$ nanoparticles composite was carried out following the method previously reported in the literature [18].

\subsection{Characterization}

\subsubsection{Scanning electron microscopy (SEM) and transmission electron microscopy (TEM)}

For scanning electron microscopy (SEM) observations, the biosorbents, $\mathrm{Fe}-\mathrm{Cu}$ nanoparticles and $\mathrm{ZM} / \mathrm{Fe}-\mathrm{Cu}$ nanoparticles composites samples, before and after malachite green adsorption, were mounted directly on the holders and then observed at $20 \mathrm{kV}$ in a JEOL JSM-5900-LD electron microscope. The microanalysis was done with an EDS (Energy X-ray Dispersive Spectroscopy) system. Transmission electron microscopy (TEM) observations of $\mathrm{Fe} / \mathrm{Cu}$ nanoparticles were carried out at $200 \mathrm{kV}$ using a JEM-2010F FASTEM microscope.

\subsubsection{X-ray diffraction (XRD)}

XRD analysis was carried out on a Siemens D500 X-ray diffractometer operated with an accelerating voltage of $40 \mathrm{kV}$, with Bragg-Bretano chamber, X-ray source $\mathrm{Cu} \mathrm{k} \alpha, \lambda=1.5406 \AA$, and current emission of $30 \mathrm{~mA}$. The conventional diffractograms were used to identify the material structures of biosorbents, $\mathrm{Fe}-\mathrm{Cu}$ nanoparticles and $\mathrm{ZM} / \mathrm{Fe}-\mathrm{Cu}$ composites.

\subsubsection{IR spectroscopy}

The IR spectra in the $4000-400 \mathrm{~cm}^{-1}$ range were recorded for all adsorbents at room temperature using a Nicolet Magna IRTM 550 FTIR. The samples were prepared using the standard $\mathrm{KBr}$ pellet method.

\subsubsection{Specific surface areas}

Specific surface areas were determined by the $\mathrm{N}_{2}$ BrunauerEmmett-Teller (BET) nitrogen adsorption method in a Micromeritics $^{\mathbb{R}}$ Gemini 2360 surface area analyzer. The dry and degassed samples were then analyzed using a multipoint $\mathrm{N}_{2}$ adsorption-desorption method at room temperature.

2.2.5. Zero charge point and concentrations of the acid-base groups

The experiments were carried out with all materials and $0.01 \mathrm{M}$ $\mathrm{NaCl}$ solutions, whose $\mathrm{pH}$ values were previously adjusted between 2 and 8 , with intervals of 2 units by adding $0.1 \mathrm{M} \mathrm{HCl}$ or $\mathrm{NaOH}$ solutions. After $24 \mathrm{~h}$ of contact, the samples were centrifuged, decanted, and $\mathrm{pH}$ was analyzed in the final liquid phases with a Hanna Instruments $\mathrm{HI} 2550 \mathrm{pH}$ meter.

Determination of acid-base groups concentrations was performed as follows: samples of $20 \mathrm{mg}$ of each adsorbent were put in contact with $25 \mathrm{~mL}$ of a $0.025 \mathrm{M} \mathrm{HCl}$ solution, using dark glass bottles, and shaken for $24 \mathrm{~h}$ at $120 \mathrm{rpm}$ and $25^{\circ} \mathrm{C}$. After that, the samples were decanted and the excess acid was titrated with $0.025 \mathrm{M} \mathrm{NaOH}$ to determine superficial basicity. The superficial acidity was obtained by a similar procedure, a $0.025 \mathrm{M} \mathrm{NaOH}$ solution was put in contact with each adsorbent and the solutions were titrated using a $0.025 \mathrm{M} \mathrm{HCl}$ solution. The experiments were done in duplicate.

\subsection{Adsorption kinetics}

Kinetic removal of malachite green (MG) by biosorbents, $\mathrm{Fe}-\mathrm{Cu}$ nanoparticles or ZM/Fe-Cu composites, was performed as follows: 

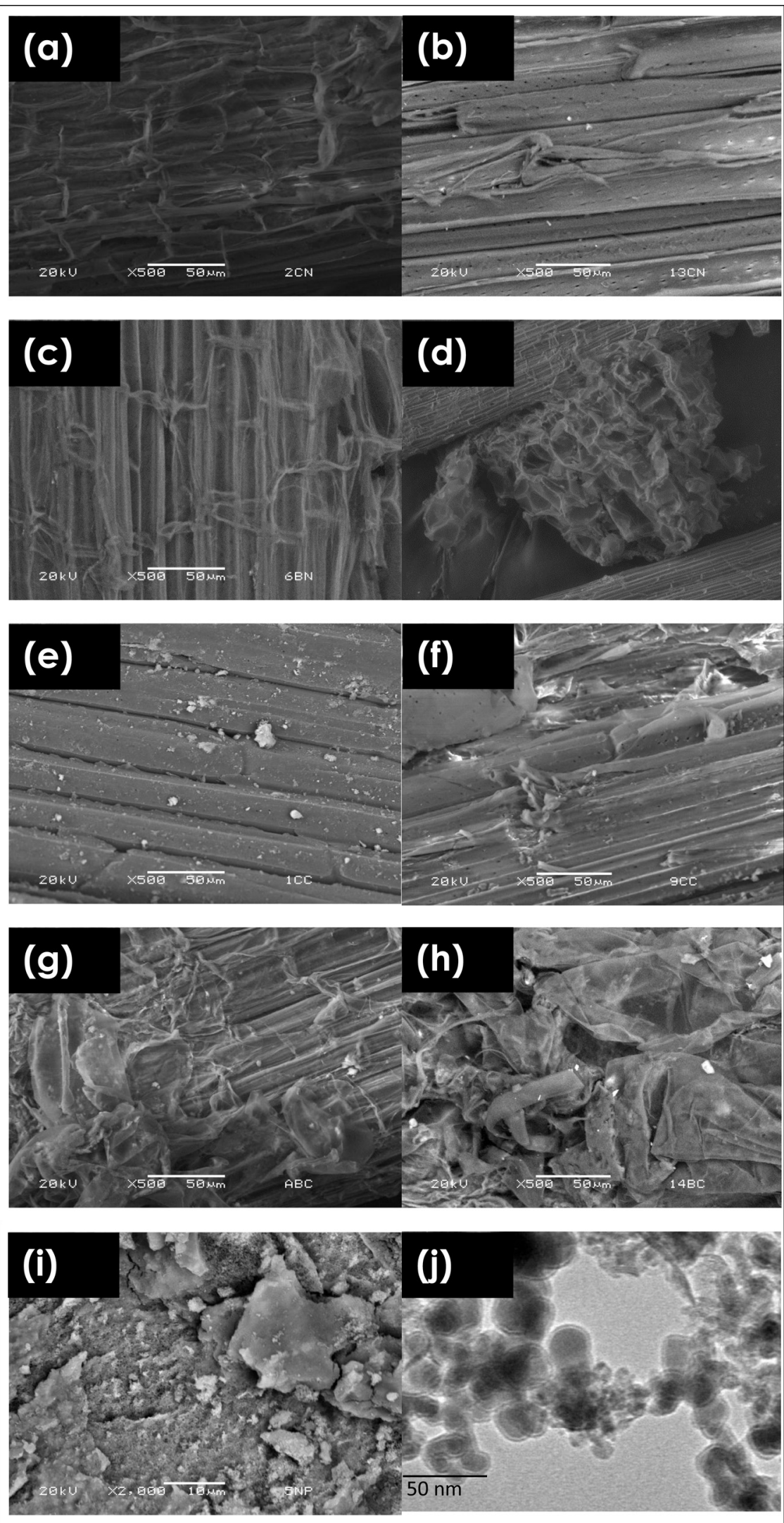

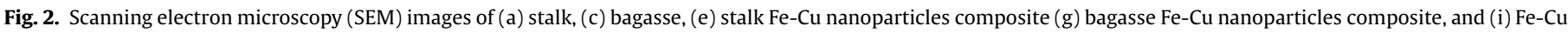
nanoparticles before malachite green sorption and (b), (d), (f), (h) after sorption experiments; (j) TEM of Fe-Cu nanoparticles. 
samples of $10 \mathrm{mg}$ of each adsorbent and $10 \mathrm{~mL}$ aliquots of a $10 \mathrm{mg} / \mathrm{L}$ solution ( $\mathrm{pH} \mathrm{6.5)}$ were placed in centrifuge tubes and shaken for different times (5, 15 and $30 \mathrm{~min}, 1,3,5,7,24,48$ and $72 \mathrm{~h}$ ) at $120 \mathrm{rpm}$ and room temperature (about $25^{\circ} \mathrm{C}$ ). Then, samples were centrifuged and decanted. All batch experiments were performed in duplicate. Malachite green concentrations were determined by using a UV/Vis PerkingElmer Lambda 10 ultraviolet-visible spectrophotometer analyzer, with $\lambda=620 \mathrm{~nm}$. The $\mathrm{pH}$ of each solution was measured before and after treatments.

\subsection{Adsorption isotherms}

$10 \mathrm{mg}$ samples of each adsorbent (biosorbents, ZM/Fe-Cu composites and $\mathrm{Fe}-\mathrm{Cu}$ nanoparticles) were put in contact with $10 \mathrm{~mL}$ of malachite green solutions of different concentrations $(1,5$, $10,20,30,40,50,70,80,100$ and $150 \mathrm{mg} / \mathrm{L}$ ) for 24,10 and 2 hours at room temperature. Malachite green concentrations were determined in the liquid phases as described above, and the $\mathrm{pH}$ was measured in each solution.

The equilibrium sorption capacity was calculated using Eq. (1):

$q_{\mathrm{e}}=\frac{\left(C_{\mathrm{o}}-C_{\mathrm{e}}\right) V}{M}$

where $q_{\mathrm{e}}(\mathrm{mg} / \mathrm{g})$ is the equilibrium sorption capacity, $C_{\mathrm{o}}$ and $C_{\mathrm{e}}$ are the initial and equilibrium concentration $(\mathrm{mg} / \mathrm{L})$ of malachite green, respectively, $V(\mathrm{~L})$ is the volume and $M(\mathrm{~g})$ is the weight of adsorbent.

The percent removal (\%) of dye was calculated using the following equation:

$\operatorname{Removal}(\%)=\frac{\left(C_{\mathrm{o}}-C_{\mathrm{e}}\right)}{C_{\mathrm{o}}} 100$

\subsection{Effect of $\mathrm{pH}$}

Experiments were conducted at different $\mathrm{pH}$ values. These experiments were carried out by putting in contact $10 \mathrm{mg}$ of each adsorbent and $10 \mathrm{~mL}$ aliquots of a $10 \mathrm{mg} / \mathrm{L}$ malachite green solution at $\mathrm{pH}$ values from 2 to 8 . The mixtures were shaken for $24 \mathrm{~h}$, and then the samples were centrifuged and decanted. The $\mathrm{pH}$ of each solution was measured in the remaining liquid phase and malachite green was determined.

\subsection{Effect of adsorbent dosage}

Experiments were performed with different amounts of each sorbent (from 10 to $200 \mathrm{mg}$ ) and $10 \mathrm{~mL}$ of a malachite green solution $(10 \mathrm{mg} / \mathrm{L})$ at $\mathrm{pH} 6.5$. The mixtures were shaken for $24 \mathrm{~h}$, and then the samples were centrifuged and decanted.

\section{Results and discussion}

\subsection{Characterization of the adsorbent}

\subsubsection{Scanning electron microscopy (SEM) and transmission electron} microscopy (TEM)

The SEM micrographs of the stalk, bagasse, stalk $\mathrm{Fe}-\mathrm{Cu}$ nanoparticles composite, bagasse $\mathrm{Fe}-\mathrm{Cu}$ nanoparticles composite and $\mathrm{Fe}-\mathrm{Cu}$ nanoparticles before and after malachite green adsorption are shown in Fig. 2. This figure $(\mathrm{a}-\mathrm{h})$ shows cellular structure composed by subset of tubes of $10 \times 50 \mu \mathrm{m}$, through which nutrients are transported to the rest of the plant [19]. The surface of stalk and Fe-Cu stalk nanoparticles composite (Fig. 2 a and c) is smoother in comparison with that of bagasse and $\mathrm{Fe}-\mathrm{Cu}$ bagasse nanoparticles composite (Fig. 2 b and d), while bagasse and bagasse composite showed coarse surfaces (Fig. $2 b$ and d). This morphology has low porosity, which is typical for raw biomaterials [20]. Vučurović et al. describe the stems of maize (stalk and bagasse), which is essentially made of parenchymatous ground tissue with the vascular bundles embedded in it [21]. The wall of parenchymatous cells is built up of cellulose, while the major cell wall component of vascular elements is lignin (Fig. 2a-h). Fig. 2d shows polyhedron and hexagonal structures similar to honeycomb with fine threads on the hexagonal structures, which are characteristic of parenchymatous tissue.

Fig. $2 \mathrm{i}$ shows the SEM micrograph of Fe-Cu nanoparticles before malachite green sorption. It can be seen that the material exhibits a rough surface with small pores [22]. The morphology and structure of the Fe-Cu nanoparticles is shown in the TEM image (Fig. 2i). Nanoparticles have diameters in the range of $5-40 \mathrm{~nm}$ with predominance of $15 \mathrm{~nm}$, TEM image reveals spherical (core-shell) particles as the main morphology, connected in chains of beads or agglomerates of different sizes also show some sheet-like particles $(5 \times 50 \mathrm{~nm})$.

EDS analysis was carried out in different areas at $500 \times$ for each adsorbent material. Table 1 shows EDS analysis for biosorbents, $\mathrm{ZM} / \mathrm{Fe}-\mathrm{Cu}$ composites and $\mathrm{Fe}-\mathrm{Cu}$ nanoparticles. EDS analysis indicates a simple composition for both materials based in cellullose. Bagasse and stalk contain carbon and oxygen, silicon is present in the stalk and corresponds to the nutrients that the plant takes from the soil [19]. Elements such as iron and copper are also present in the $\mathrm{ZM} / \mathrm{Fe}-\mathrm{Cu}$ nanoparticle composite and $\mathrm{Fe}-\mathrm{Cu}$ nanoparticles and they may be important in sorption processes. EDS results are similar before and after adsorption experiments; however, carbon content lightly increases. The chemical composition of Fe-Cu nanoparticles before dye adsorption shows that the quantity of carbon notably increased when the samples were in contact with the dye solutions, which indicated that dye adsorption on the materials occurred.

Table 1

Elemental analysis of the stalk, Fe-Cu stalk composite, bagasse, Fe-Cu bagasse composite and Fe-Cu nanoparticles before and after malachite green adsorption by EDS.

\begin{tabular}{|c|c|c|c|c|c|c|c|c|c|c|}
\hline Element & $\begin{array}{l}\text { Weight } \\
\text { percent } \\
\text { Stalk }\end{array}$ & $\begin{array}{l}\text { Weight } \\
\text { percent } \\
\text { Stalk-MG }\end{array}$ & $\begin{array}{l}\text { Weight } \\
\text { percent } \\
\text { Fe-Cu stalk } \\
\text { composite }\end{array}$ & $\begin{array}{l}\text { Weight percent } \\
\text { Fe-Cu stalk } \\
\text { composite -MG }\end{array}$ & $\begin{array}{l}\text { Weight } \\
\text { percent } \\
\text { Bagasse }\end{array}$ & $\begin{array}{l}\text { Weight } \\
\text { percent } \\
\text { Bagasse- } \\
\text { MG }\end{array}$ & $\begin{array}{l}\text { Weight } \\
\text { percent } \\
\text { Fe-Cu bagasse } \\
\text { composite }\end{array}$ & $\begin{array}{l}\text { Weight percent } \\
\text { Fe-Cu bagasse } \\
\text { composite-MG }\end{array}$ & $\begin{array}{l}\text { Weight } \\
\text { percent } \\
\text { Fe-Cu } \\
\text { Nanoparticles }\end{array}$ & $\begin{array}{l}\text { Weight } \\
\text { percent } \\
\text { Fe-Cu } \\
\text { Nanoparticles- } \\
\text { MG }\end{array}$ \\
\hline C & $54.57 \pm 0.43$ & $57.25 \pm 1.59$ & $51.46 \pm 1.38$ & $56.53 \pm 1.08$ & $53.30 \pm 2.25$ & $56.45 \pm 0.57$ & $53.93 \pm 1.17$ & $55.45 \pm 1.30$ & $9.05 \pm 0.91$ & $21.767 \pm 13.56$ \\
\hline $\mathrm{O}$ & $44.95 \pm 0.64$ & $41.90 \pm 1.97$ & $43.69 \pm 1.76$ & $42.73 \pm 1.39$ & $46.70 \pm 2.25$ & $43.54 \pm 0.57$ & $43.47 \pm 1.23$ & $42.90 \pm 0.91$ & $17.79 \pm 2.24$ & $12.75 \pm 6.73$ \\
\hline $\mathrm{Al}$ & - & $0.46 \pm 1.04$ & - & - & - & - & $0.24 \pm 0.22$ & - & - & $0.61 \pm 0.53$ \\
\hline $\mathrm{Si}$ & $0.49 \pm 0.20$ & $0.38 \pm 0.85$ & - & $0.29 \pm 0.17$ & - & - & $0.14 \pm 0.01$ & - & - & $0.09 \pm 0.15$ \\
\hline$S$ & - & - & - & - & - & - & - & - & - & $0.11 \pm 0.20$ \\
\hline $\mathrm{Fe}$ & - & - & $4.85 \pm 2.44$ & $0.46 \pm 0.33$ & - & - & $1.43 \pm 0.39$ & $1.64 \pm 0.46$ & $55.72 \pm 2.74$ & $52.91 \pm 22.99$ \\
\hline $\mathrm{Cu}$ & - & - & - & - & - & - & $0.78 \pm 0.07$ & - & $17.44 \pm 2.51$ & $11.72 \pm 4.46$ \\
\hline
\end{tabular}




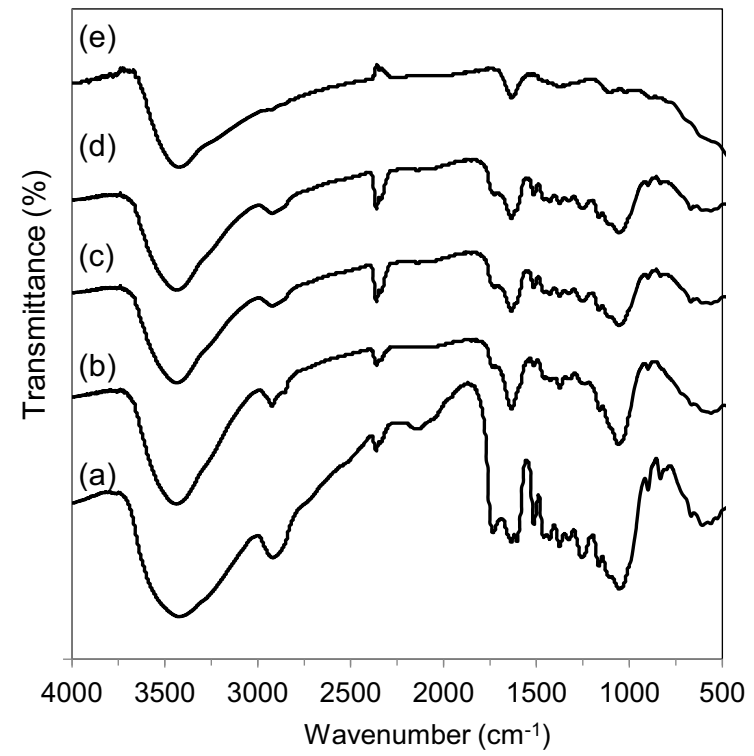

Fig. 3. IR spectrum of (a) stalk, (b) bagasse, (c) stalk Fe-Cu nanoparticles composite (d) bagasse $\mathrm{Fe}-\mathrm{Cu}$ nanoparticles composite and (e) $\mathrm{Fe}-\mathrm{Cu}$ nanoparticles.

\subsubsection{IR spectroscopy}

The FT-IR spectra of biosorbents, their composites (ZM/Fe-Cu nanoparticles) and $\mathrm{Fe}-\mathrm{Cu}$ nanoparticles before sorption of dye are presented in Fig. 3. Biosorbents and their composites show a broad band at $3431 \mathrm{~cm}^{-1}$, which is due to the stretching vibration of $-\mathrm{OH}$ groups [23]. The bands at $2922 \mathrm{~cm}^{-1}$ are attributed to $\mathrm{C}-\mathrm{H}$ stretching vibrations [20]. The strong band at $1633 \mathrm{~cm}^{-1}$ is $\mathrm{C}=\mathrm{O}$ stretching vibration that may be attributed to the lignin aromatic groups or to carboxylic acid [19,20]. The $\mathrm{CH}$ deformation vibration appears at $1375.53 \mathrm{~cm}^{-1}$, band emergence in the region between 1200 and $800 \mathrm{~cm}^{-1}$ showed several absorption bands characteristic of carbohydrates [24]. The $\mathrm{C}-\mathrm{O}$ band stretching vibration of the cellulose occurred at about $1055.80 \mathrm{~cm}^{-1}$ [19], and finally, the band at $832.32 \mathrm{~cm}^{-1}$ was assigned to the bending modes of aromatic compounds as pyranose [24].

The IR spectrum of $\mathrm{Fe}-\mathrm{Cu}$ nanoparticles shows a number of absorption bands at $3431.2 \mathrm{~cm}^{-1}$ corresponding to the $-\mathrm{OH}$ vibration and the band at $1632.44 \mathrm{~cm}^{-1}$ can be assigned to $-\mathrm{OH}$ bending of absorbed water [25].

The adsorbent-Fe-Cu composites showed the absorption bands at 3432 and $1633 \mathrm{~cm}^{-1}$ shifted and increased; probably a large number of $-\mathrm{OH}$ groups were introduced in the materials and it suggests that this functional group plays an important role on the adsorption process (Fig. 3).

IR spectra of the all adsorbents were obtained after malachite green adsorption (figures do not show). The bands centered at 3431.2 and $1632.44 \mathrm{~cm}^{-1}$ assigned to hydroxyl groups of adsorbents, their transmittance decreased considerably, suggesting that these groups are probably involved in the binding of malachite green to the adsorbent. When malachite green was dissolved in aqueous solution, they were positively charged [26] and showed attraction to the $\mathrm{OH}$-group from adsorbents. Zou et al. observed similar changes, when a pyrolytic char was treated in a muffle furnace (TPC) and was used as an adsorbent for the removal of neutral red dye and $\mathrm{Cu}^{2+}$ ions from aqueous solutions in a batch system. This study reported that hydroxy and carboxyl groups of TPC adsorbent were involved in coordination with the positive dye and heavy ions [27]. Petrović et al. used corn silk as adsorbent for lead removal in aqueous solution and found that the intensity of the bands in FT-IR spectra decreased after $\mathrm{Pb}^{2+}$ adsorption and the position of the bands of some functional groups changed [20].

\subsubsection{Specific surface areas}

The BET specific surface areas of the adsorbents were 4.79, 20.63, 6.92, 26.37 and $63.81 \mathrm{~m}^{2} / \mathrm{g}$ for stalk, Fe-Cu stalk composite, bagasse, $\mathrm{Fe}-\mathrm{Cu}$ bagasse composite and $\mathrm{Fe}-\mathrm{Cu}$ nanoparticles respectively. The specific surface areas of the natural materials increased when the samples were treated with the $\mathrm{Fe}-\mathrm{Cu}$ nanoparticles to obtain the composites and the highest specific surface area was for Fe-Cu nanoparticles.

\subsubsection{Point of zero charge (PZC) and concentrations of the acid-base groups}

The pH-dependent charging of solid surfaces in electrolyte aqueous solutions is an important theoretical and practical indicator of the net surface charge of adsorbents and their preference to ionic species [28]. The PZC of the adsorbents were $6.8,6.5,6.8,7.6$ and 7.5 for stalk, Fe-Cu stalk composite, bagasse, Fe$\mathrm{Cu}$ bagasse composite and $\mathrm{Fe}-\mathrm{Cu}$ nanoparticles respectively. An adsorbent will retain anions when the $\mathrm{pH}$ is lower than its PZC, because positively charged sites are predominant on the surface of the adsorbent, while an opposite behavior will be presented when the $\mathrm{pH}$ is higher than the PZC.

The acid and base groups concentrations are shown in Table 2, although the result do not show a clear tendency with respect to the adsorption capacities determined by Langmuir model, it seems that the adsorption capacities increased with decreasing the acid groups in the samples. Fig. 7 shows the concentration of $\mathrm{OH}^{-}$ groups vs. the adsorption capacity of each adsorbent, it is clear that the adsorption of the dye depends on the concentration of $\mathrm{OH}^{-}$ groups.

The initial $\mathrm{pH}$ of the solutions was 5.2 and in the remaining solutions, 5.0 and 7.4 for the bagasse and for the bagasse composite, respectively.

\subsection{5. $X$-ray diffraction (XRD)}

The X-ray powder diffraction pattern of the Fe-Cu nanoparticles shows that the material is amorphous. However the diffractogram was compared with paramelaconite $\left(\mathrm{Cu}_{4} \mathrm{O}_{3}\right)$ (JCPDS 49-1830), maghemite $\left(\mathrm{Fe}_{2} \mathrm{O}_{3}\right)$ (JCPDS 39-1346) and magnetite $\left(\mathrm{Fe}_{3} \mathrm{O}_{4}\right)$ (JCPDS 01-1111) which were the principal components found in the $\mathrm{Fe}-\mathrm{Cu}$ nanoparticles, also these results suggest there are not any notable change in structure of material after it was treated with malachite green solution.

Table 2

Physical properties of adsorbents.

\begin{tabular}{|c|c|c|c|c|}
\hline Material & $S_{\text {BET }}\left(\mathrm{m}^{2} / \mathrm{g}\right)$ & Zeropoint charge & $\mathrm{H}^{+}$groups $(\mathrm{meq} / \mathrm{g})$ & $\mathrm{OH}^{-}$groups $(\mathrm{meq} / \mathrm{g})$ \\
\hline Stalk & 4.79 & 6.8 & 68.56 & 392.70 \\
\hline Fe-Cu stalk composite & 20.63 & 6.5 & 89.44 & 351.02 \\
\hline Bagasse & 6.92 & 6.8 & 114.95 & 446.85 \\
\hline Fe-Cu bagasse composite & 26.37 & 7.6 & 80.30 & 444.81 \\
\hline Fe-Cu Nanoparticles & 63.81 & 7.5 & 52.37 & 1129.56 \\
\hline
\end{tabular}




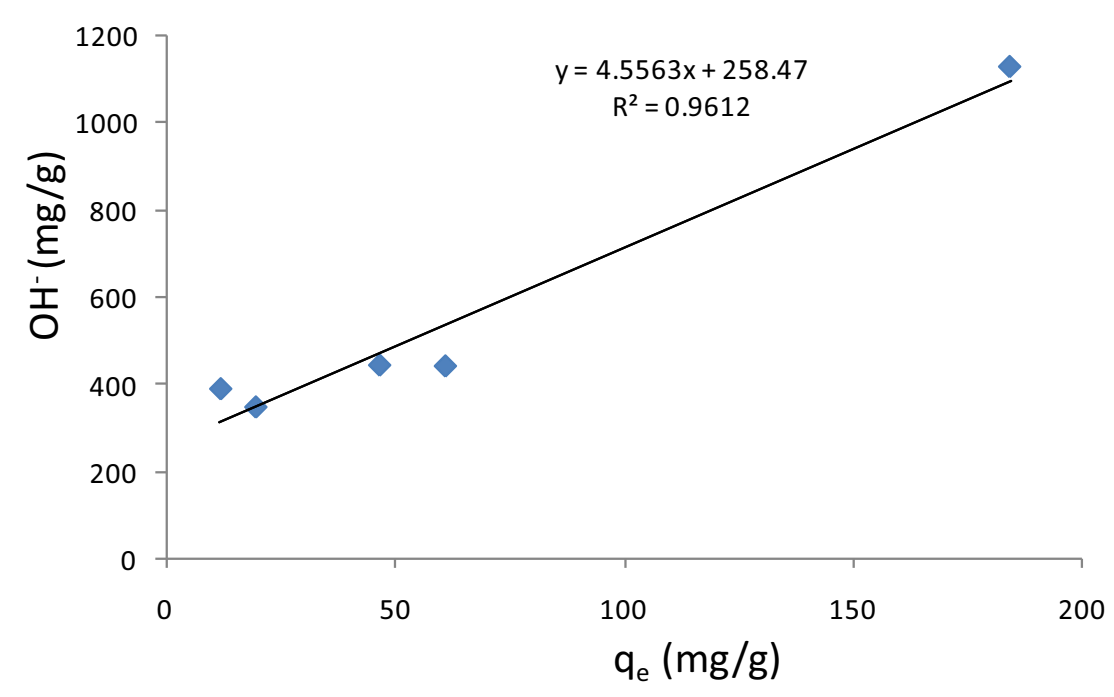

Fig. 7. Groups OH vs. Adsorption capacities for removal malachite green.
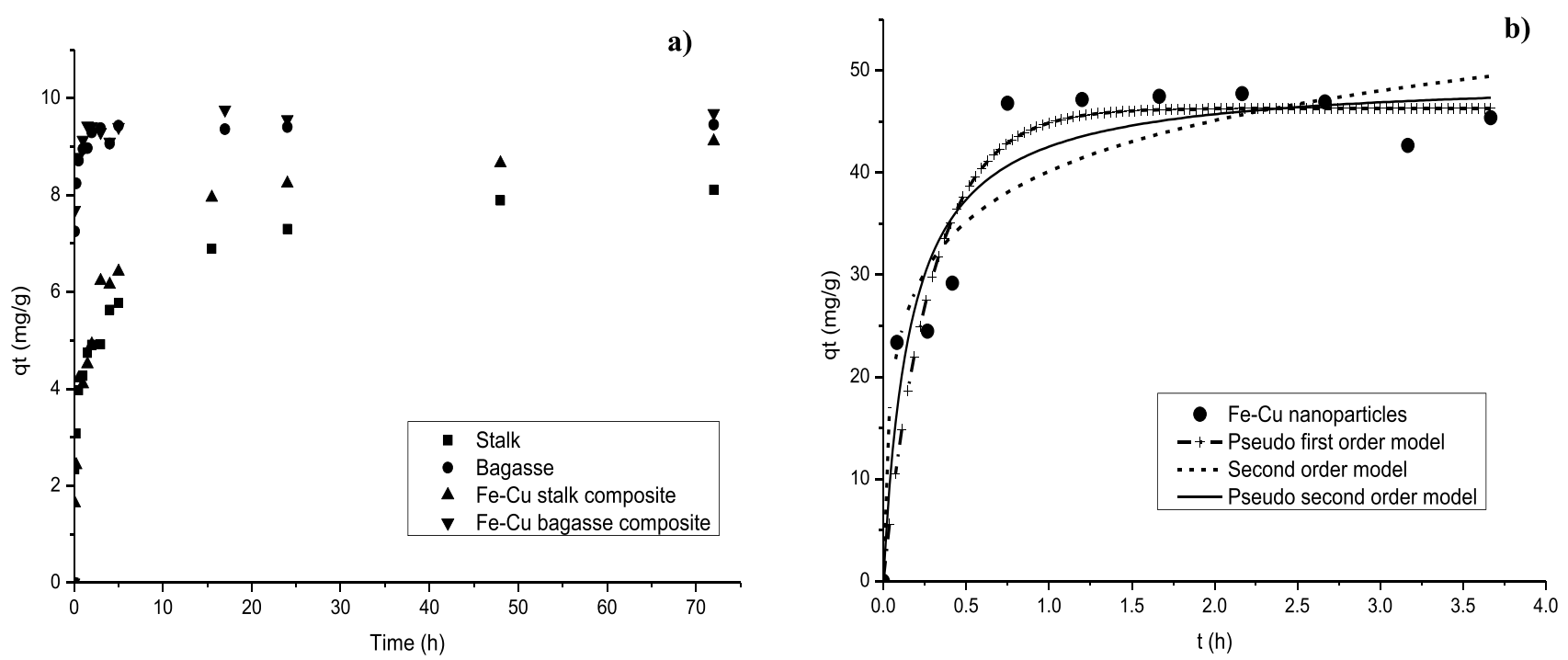

Fig. 4. (a) Sorption kinetics of malachite green by maize cane, their composites and (b). Fe-Cu nanoparticles and adjustments to kinetic models.

\subsection{Sorption kinetics}

Fig. 4a shows the relationship between contact time and the dye adsorption capacities of bagasse, $\mathrm{Fe}-\mathrm{Cu}$ bagasse composite, stalk, Fe-Cu stalk composite and Fig. 4b for Fe-Cu nanoparticles. According to the kinetic curves, adsorption malachite green rate rapidly increased during the first hours of the processes and then became slower until the equilibriums were gradually reached in
$5 \mathrm{~h}$ for bagasse and its composite. In $20 \mathrm{~h}$ for stalk and its composite; Fe-Cu nanoparticles showed the shortest time to reach the equilibrium (less than one hour) and the adsorption was 5 times higher in comparison to the other adsorbents. In order to determine the kinetics parameters of the adsorption process, the pseudo-first-order [29], pseudo-second-order [30,31], secondorder [32] and intraparticle diffusion kinetic model [33] were applied:

Table 3

Kinetic parameters of the malachite green adsorption by maize cane, their composites and Fe-Cu nanoparticles.

\begin{tabular}{|c|c|c|c|c|c|c|c|c|c|}
\hline \multirow[t]{3}{*}{ Material } & \multicolumn{9}{|c|}{ Kinetic models } \\
\hline & \multicolumn{3}{|l|}{ First order } & \multicolumn{2}{|c|}{ Second order } & \multirow[b]{2}{*}{$R^{2}$} & \multicolumn{3}{|c|}{ Pseudo-second order } \\
\hline & $q_{\mathrm{e}}(\mathrm{mg} / \mathrm{g})$ & $K_{\mathrm{L}}\left(\mathrm{h}^{-1}\right)$ & $R^{2}$ & $a(\mathrm{mg} / \mathrm{g})$ & $b(\mathrm{mg} / \mathrm{g})$ & & $q_{\mathrm{e}}(\mathrm{mg} / \mathrm{g})$ & $K(\mathrm{~g} / \mathrm{mgh})$ & $R^{2}$ \\
\hline Stalk & 6.52 & 1.28 & 0.7355 & 118.48 & 1.12 & 0.9952 & 7.11 & 0.25 & 0.8712 \\
\hline Fe-Cu stalk composite & 7.97 & 0.60 & 0.8527 & 47.84 & 0.84 & 0.9832 & 8.45 & 0.11 & 0.9346 \\
\hline Bagasse & 9.10 & 18.53 & 0.9820 & $1.20 \mathrm{E} 13$ & 3.61 & 0.9822 & 9.29 & 4.21 & 0.9967 \\
\hline Fe-Cu bagasse composite & 9.28 & 20.91 & 0.9890 & $1.57 \mathrm{E} 15$ & 4.06 & 0.9879 & 9.46 & 5.25 & 0.9970 \\
\hline Fe-Cu nanoparticles & 46.30 & 3.47 & 0.8958 & 1901.06 & 0.13 & 0.8897 & 49.41 & 0.12 & 0.9042 \\
\hline
\end{tabular}


Pseudo-first order model (Langergren):

$q_{\mathrm{t}}=q_{\mathrm{e}}\left(1-e^{K_{\mathrm{L}} t}\right)$

Second order model (Elovich):

$q_{\mathrm{t}}=\frac{1}{a} \ln (1+a b t)$

Pseudo-second-order (Ho):

$q_{\mathrm{t}}=\frac{q_{\mathrm{e}}^{2} k t}{1+q_{\mathrm{e}} k t}$

Intraparticle diffusion:

$q_{\mathrm{t}}=k_{\mathrm{d}} t^{0.5}+\mathrm{C}$

where $k_{\mathrm{L}}$ is the pseudo-first-order rate constant, $q_{\mathrm{e}}$ and $q_{\mathrm{t}}$ are the adsorption capacities at equilibrium and time $t$ respectively, $a$ the initial adsorption rate, and $b$ is the desorption constant during any one experiment, $k$ relates to the constant of pseudo-secondorder adsorption, $k_{\mathrm{d}}$ is the rate constant and $C$ is a constant for any experiment. The kinetic parameters and coefficients of determination for each model are shown in Table 3. The data of stalk and its composite were best fitted to Elovich model, which indicates chemisorption and for the other adsorbents to the pseudo-second order model, the $q_{\mathrm{e}}$ values obtained with this last model are very similar to the experimental values. This model was proposed by Ho and McKay [34], and it is based on the assumption that the ratelimiting step may be the chemisorption involving valence forces through the sharing or exchange of electrons between adsorbent and adsorbate.

Data were adjusted to the intraparticle diffusion model; the diffusion model plots are shown in Fig. 5 and its parameters in Table 4, it can be observed that the processes involve three phases for the natural materials and two for treated or synthetic materials. Allen et al. investigated a basic dye adsorption on peat and attributed the diffusion of the three regions to macropore diffusion, transitional pore diffusion, and micropore diffusion, respectively [35]. The two-phase plot suggests that the adsorption process proceeds by surface sorption and intraparticle diffusion [36]. The initial curved portion of the plot indicated a boundarylayer effect while the second linear portion is due to intraparticle or pore diffusion [37].

In addition, the intraparticle diffusion model does not pass the origin (Fig. 5); this indicates the coexistence other mechanisms involved such as external film and intra-particle diffusions [38]. The adsorption of malachite green by composites and $\mathrm{Fe}-\mathrm{Cu}$ nanoparticles was faster than maize cane probably due to availability of active sites on the adsorbent surface.

\subsection{Adsorption isotherms}

Fig. 6 shows the malachite green sorption equilibrium experiments carried out for bagasse, Fe-Cu bagasse composite, stalk, Fe$\mathrm{Cu}$ stalk composite and $\mathrm{Fe}-\mathrm{Cu}$ nanoparticles. It can be observed that the degree of dye removal by natural bagasse and stalk increased 69 and 30\% respectively, after they were treated to obtain the composites. Fe-Cu nanoparticles showed the highest adsorption capacity for the dye. According to classification of Giles, the adsorption isotherms are classified into four groups: $\mathrm{L}, \mathrm{S}, \mathrm{H}$, and C. The adsorption of Malachite green onto the adsorbents followed the L curve pattern which indicates that there is no strong competition between solvent and the adsorbate to occupy the adsorbent surface sites [8].

Experimental results were analyzed by Langmuir, Freundlich and Langmuir-Freundlich adsorption models. An adsorption isotherm represents the equilibrium relationship between the
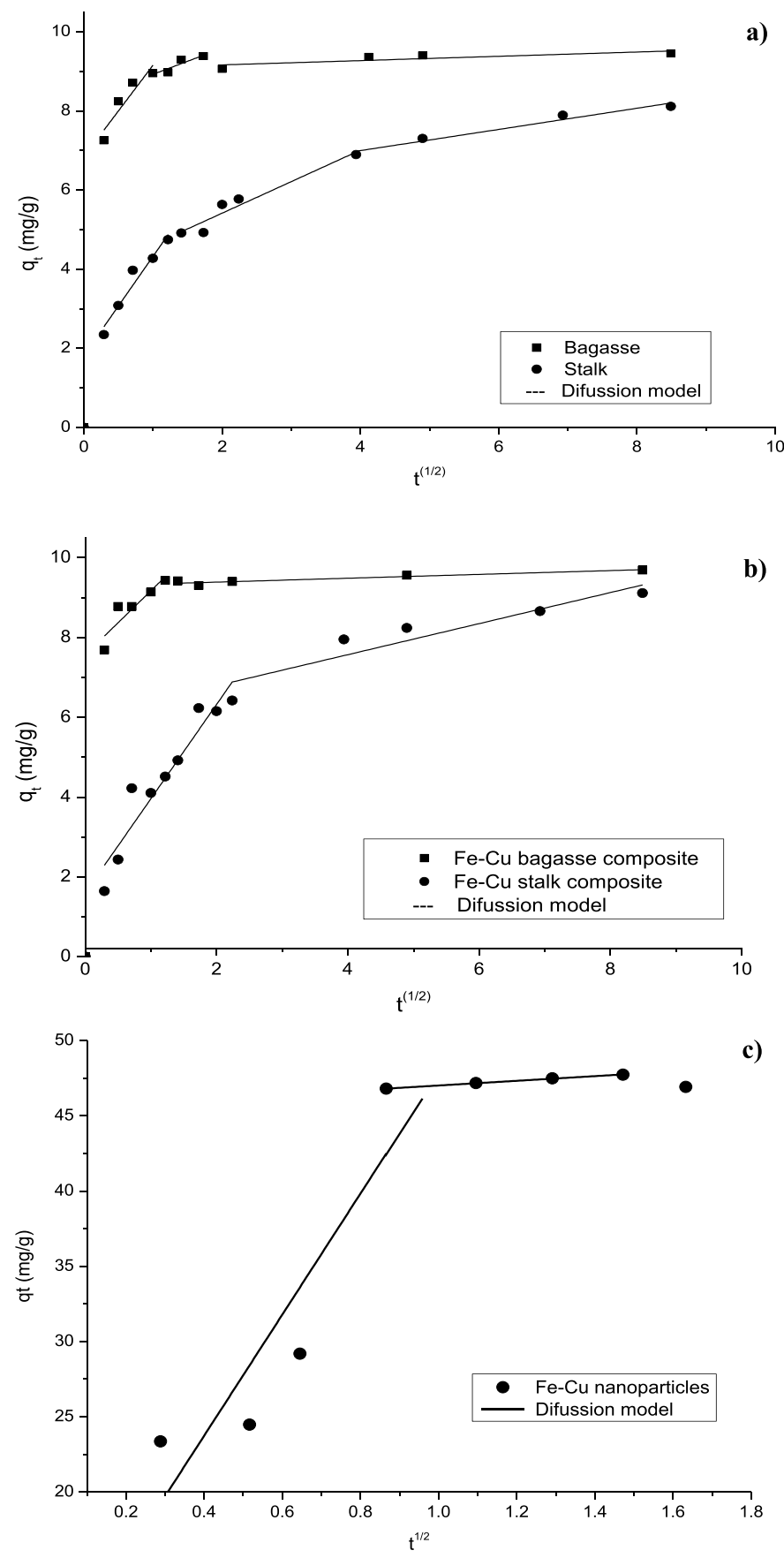

Fig. 5. Intraparticle diffusion plots for malachite green adsorption by (a) maize cane, (b) their composites and (c) Fe-Cu nanoparticles.

adsorbate concentration in the liquid phase and that on the adsorbent's surface at a given conditions. In the present study, the

Table 4

Diffusion parameters of the malachite green adsorption by studied adsorbents. (K, $\mathrm{mg} \mathrm{g}^{-1} \mathrm{~min}^{-1 / 2}$ ).

\begin{tabular}{lllllll}
\hline Material & $K_{1}$ & $K_{2}$ & $K_{3}$ & $R_{1}{ }^{2}$ & $R_{2}{ }^{2}$ & $R_{3}{ }^{2}$ \\
\hline Stalk & 2.5057 & 0.7967 & 0.2676 & 0.9273 & 0.9200 & 0.9485 \\
Bagasse & 2.3135 & 0.6588 & 0.0542 & 0.8051 & 0.7900 & 0.5473 \\
Fe-Cu stalk composite & 2.3621 & 0.3893 & - & 0.8976 & 0.8325 & - \\
Fe-Cu bagasse composite & 1.6038 & 0.0480 & - & 0.7690 & 0.8501 & - \\
Fe-Cu nanoparticles & 7.6487 & 1.5527 & - & 0.7005 & 0.9984 & - \\
\hline
\end{tabular}




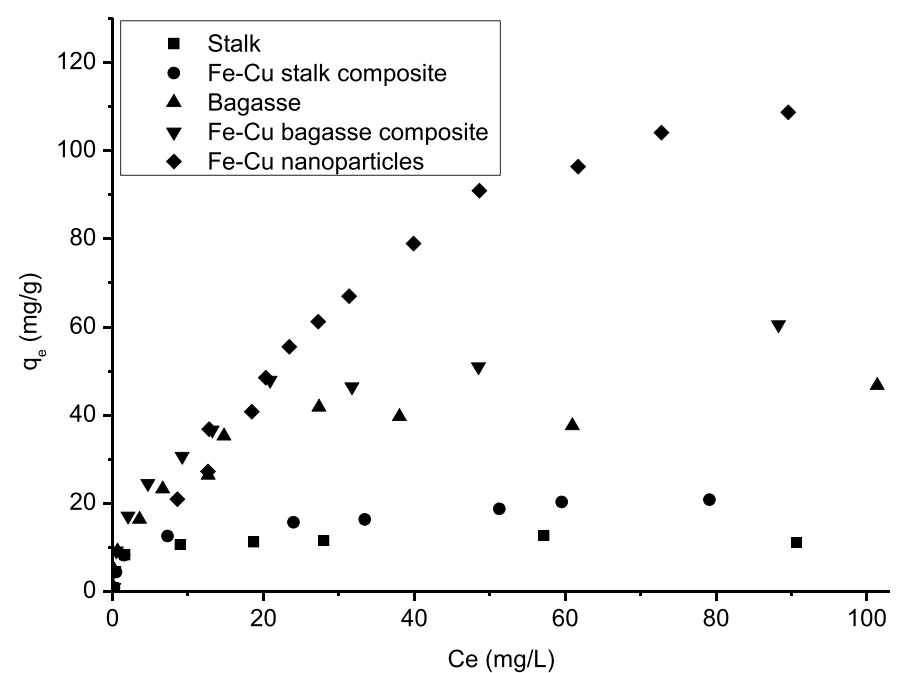

Fig. 6. Isotherm of malachite green dye by maize cane, their composites and $\mathrm{Fe}-\mathrm{Cu}$ nanoparticles.

Langmuir [39], Freundlich [9,33] and Langmuir-Freundlich models [40] were used to describe the equilibrium data.

Langmuir:

$q_{\mathrm{e}}=\frac{q_{o} b C_{\mathrm{e}}}{1+b C_{\mathrm{e}}}$

Freundlich:

$q_{\mathrm{e}}=K_{\mathrm{F}} C_{\mathrm{e}}^{\frac{1}{n}}$

Langmuir-Freundlich:

$q_{\mathrm{e}}=\frac{K_{L-F} C_{e}^{1 / n}}{1+b C_{\mathrm{e}}^{1 / n}}$

where $C_{\mathrm{e}}$ is the MG concentration at equilibrium $(\mathrm{mg} / \mathrm{L}), q_{\mathrm{e}}$ is the adsorption capacity at equilibrium $(\mathrm{mg} / \mathrm{g}), K_{\mathrm{F}}((\mathrm{mg} / \mathrm{g})(\mathrm{L} / \mathrm{g}))$ and $K_{\mathrm{L}-}$ F, (mg.mL $\left.{ }^{-1}\right) b$ and $1 / n$ are empirical constants.

Table 5 shows the parameters obtained by applying these models to the experimental data. The results were best adjusted to the Langmuir-Freundlich model, which has been applied to adsorbents with heterogeneous surfaces and considers multilayer sorption [41].

The separation factor $\left(R_{\mathrm{L}}\right)$ indicates if an adsorption system is favorable or not, and it may be calculated from Langmuir isotherm by following equation [42]:

$R_{L}=\frac{1}{1+b C_{0}}$

where $b$ is the Langmuir constant and $C_{0}$ is the initial concentration of the dye. Value of $R_{\mathrm{L}}$ describes adsorption as irreversible $\left(R_{\mathrm{L}}=0\right)$,

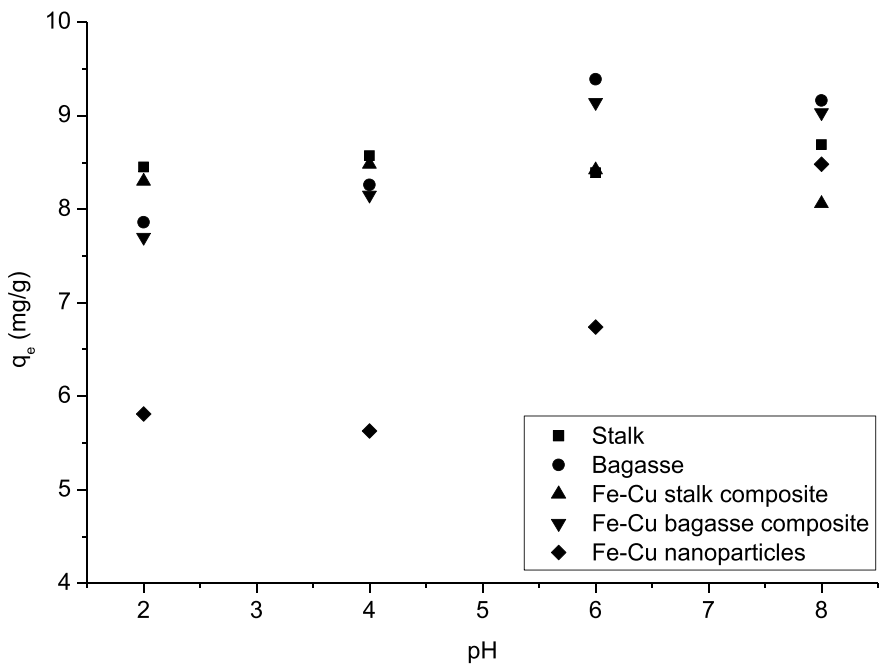

Fig. 8. $\mathrm{pH}$ effect on the adsorption of malachite green by maize cane, their composites and Fe-Cu nanoparticles.

favorable $\left(0<R_{\mathrm{L}}<1\right)$ or unfavorable $\left(R_{\mathrm{L}}>1\right)$ [42]. Calculated parameter values for malachite green adsorption by $\mathrm{Fe}-\mathrm{Cu}$ bagasse composite are between 0.071 and 0.885 for initial concentrations of the dye from 1 to $100 \mathrm{mg} \mathrm{L}^{-1}$, which shows that the process is favorable. Similar results were found for bagasse, stalk, their composite and $\mathrm{Fe}-\mathrm{Cu}$ nanoparticles.

\subsection{Effect of $p H$ on dye uptake}

The $\mathrm{pH}$ of an aqueous solution is an important monitoring parameter in dye adsorption, because as it affects the surface charge of the adsorbent and the degree of ionization of the dye molecule. $\mathrm{pH}$ has also been associated with changes in the structural stability and color intensity of the dye molecule. In addition, it is directly related to competition ability of hydrogen ions with adsorbate ions to active sites on the adsorbent surface [43]. Adsorption behaviors of dye were similar for the bagasse and its composite and the adsorption capacities were similar from $\mathrm{pH}$ 2 to 8 (Fig. 8). Similar adsorption behaviors were observed for stalk and its composite and their maximum adsorption capacities were found at $\mathrm{pH}$. The adsorption capacities of nanoparticles increased with increasing the $\mathrm{pH}$ from 4 to 8 .

Mohammadi et al. [14] studied the malachite green onto alginate- $\mathrm{Fe}_{3} \mathrm{O}_{4}$ nanoparticles at various $\mathrm{pH}$ values and found that at basic $\mathrm{pH}$ values, most of the carboxylic and hydroxyl groups of sodium alginates were ionized and interacted with the cationic dye molecules via the strong electrostatic interaction, which was favorable to increase the malachite green adsorption.

Table 5

Langmuir, Freundlich and Langmuir-Freundlich parameters for maize cane, their composites and Fe-Cu nanoparticles.

\begin{tabular}{|c|c|c|c|c|c|c|c|c|c|c|}
\hline \multirow[t]{3}{*}{ Material } & \multicolumn{10}{|c|}{ Sorption isotherms } \\
\hline & \multicolumn{3}{|l|}{ Langmuir } & \multicolumn{3}{|l|}{ Freundlich } & \multicolumn{4}{|c|}{ Langmuir-Freundlich } \\
\hline & $q_{\mathrm{o}}(\mathrm{mg} / \mathrm{g})$ & $b$ & $R^{2}$ & $K_{\mathrm{F}}(\mathrm{mg} / \mathrm{g})(\mathrm{L} / \mathrm{g})$ & $1 / n$ & $R^{2}$ & $K$ & $b$ & $1 / n$ & $R^{2}$ \\
\hline Stalk & 11.77 & 1.4 & 0.9615 & 6.00 & 0.77 & 0.7522 & 17.68 & 1.51 & 1.08 & 0.9548 \\
\hline Fe-Cu stalk composite & 19.46 & 0.36 & 0.9449 & 6.11 & 0.29 & 0.9594 & 7.36 & 0.27 & 0.54 & 0.9723 \\
\hline Bagasse & 46.56 & 0.16 & 0.9533 & 12.60 & 0.3 & 0.9034 & 10.72 & 0.20 & 0.75 & 0.955 \\
\hline Fe-Cu bagasse composite & 60.95 & 0.13 & 0.9707 & 14.26 & 0.34 & 0.9584 & 13.16 & 0.16 & 0.65 & 0.9855 \\
\hline Fe-Cu nanoparticles & 184.46 & 0.01 & 0.9847 & 7.94 & 0.60 & 0.9556 & 1.27 & 0.0093 & 1.35 & 0.9914 \\
\hline
\end{tabular}




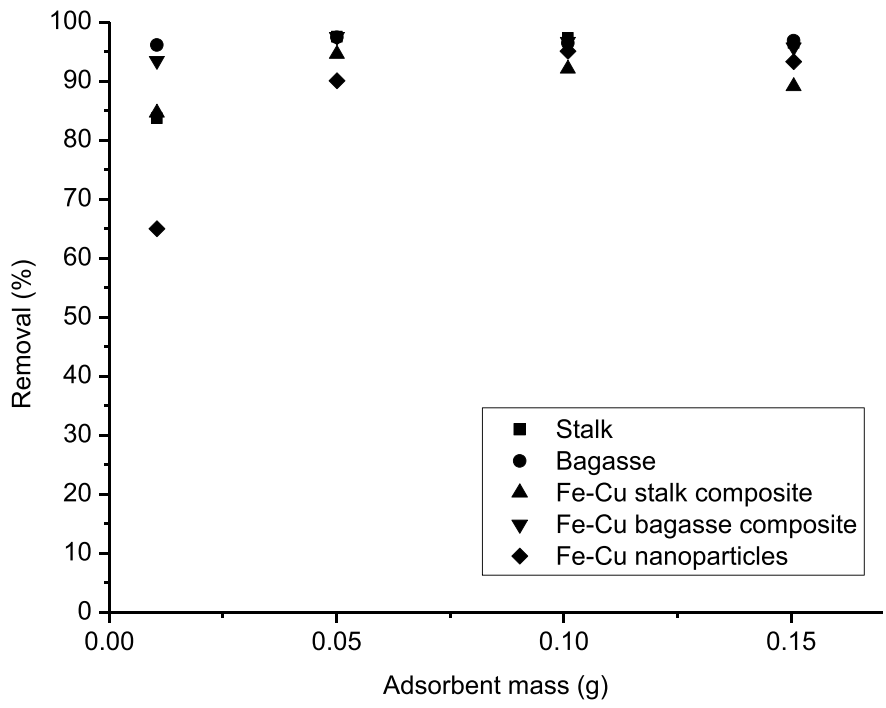

Fig. 9. Removal of malachite green by adsorbents.

Table 6

Comparison of adsorption capacities of various adsorbents for the removal of malachite green.

\begin{tabular}{|c|c|c|}
\hline Adsorbents & $q(\mathrm{mg} / \mathrm{g})$ & References \\
\hline Coconut coir activated carbon & 27.44 & [44] \\
\hline Walnut shell & 90.8 & [45] \\
\hline Beech sawdust & 83.21 & [42] \\
\hline Bivalve shell-Zea mays $L$. husk leaf & 81.5 & [9] \\
\hline Alginate-coated $\mathrm{Fe}_{3} \mathrm{O}_{4}$ nanoparticles & 47.84 & {$[14]$} \\
\hline Functionalized multi-nanotubes & 49.45 & [46] \\
\hline $\mathrm{Fe}_{3} \mathrm{O}_{4} @ \mathrm{PAmABAmPD}-\mathrm{TCAS}$ nanoadsorbent & 29.06 & [47] \\
\hline Stalk & 11.77 & This work \\
\hline Fe-Cu stalk composite & 19.46 & This work \\
\hline Bagasse & 46.56 & This work \\
\hline $\mathrm{Fe}-\mathrm{Cu}$ bagasse composite & 60.95 & This work \\
\hline Fe-Cu nanoparticles & 184.46 & This work \\
\hline
\end{tabular}

\subsection{Effect on adsorbent dosage}

The sorption capacities for malachite green were similar for all adsorbents from 0.05 to $0.15 \mathrm{~g}$. Fig. 9 illustrates malachite green sorption capacities versus adsorbent dosage. The amount of adsorbed dye increased as the quantity of sorbents increased from 0.01 to $0.05 \mathrm{~g}$ for nanoparticles, stalk and stalk composite, and then the adsorption was of the same order of magnitude.

As compared with data reported in the literature (Table 6), the Fe-Cu bagasse composite had an adsorption capacity of the same order as other natural adsorbents derived from agriculture residues such as walnut shell, beech sawdust and Zea mays $L$. husk leaf-bivalve shell. Fe-Cu nanoparticles show a higher adsorption capacity than natural adsorbents and Fe-modified adsorbents.

\section{Conclusions}

The present study demonstrated that maize cane (bagasse and stalk) and their composites ( $\mathrm{ZM} / \mathrm{Fe}-\mathrm{Cu}$ nanoparticles) can be used as an effective adsorbent for the removal of malachite green from aqueous solutions. Adsorbents were characterized by BET, infrared spectroscopy, X-ray diffraction and SEM-EDS and the presence of Fe-Cu nanoparticles was confirmed by TEM technique. The kinetic adsorption of malachite green by stalk and their composite follows second-order kinetic and nanoparticles, bagasse and their composite follow the pseudo-second order kinetic. The equilibrium data was well described by the Langmuir-Freundlich isotherm model and the adsorption was more favorable at basic $\mathrm{pH}$. The quantity of $\mathrm{OH}$ - groups was proportional to dye adsorption capacities.

\section{Acknowledgment}

We acknowledge the financial support from Universidad Autónoma del Estado de México, project 3688/2014/CIB.

\section{References}

[1] B. Mi-Hwa, C. Olakitan, O. Se-Jin, K. Dong-Su, Removal of malachite green from aqueous solution using degreased coffee vean, J. Hazard. Mater. 176 (2010) $820-828$

[2] V.K. Gupta, A. Mittal, L. Krishnan, V. Gajbe, Adsorption kinetics and column operations for the removal and recovery of malachite green from wastewater using bottom ash, Sep. Purif. Technol. 40 (2004) 87-96.

[3] B.H. Hameed, M.I. El-Khaiary, Batch removal of malachite green from aqueous solutions by adsorption on oil palm trunk fibre: Equilibrium isotherms and kinetic studies, J. Hazard. Mater. 154 (2008) 237-244.

[4] M.T. Yagub, T.K. Sen, S. Afroze, H.M. Ang, Dye and its removal from aqueous solution by adsorption: a review, Adv. Colloid Interface Sci. 209 (2014) 172 184.

[5] V.K. Gupta, Suhas, Application of low-cost adsorbents for dye removal-a review, J. Environ. Manage. 90 (2009) 2313-2342.

[6] A. Demirbas, Agricultural based activated carbons for the removal of dyes from aqueous solutions: a review, J. Hazard. Mater. 167 (2009) 1-9.

[7] E. Akar, A. Altinissik, Y. Seki, Using of activated carbon produced from spent tea leaves for the removal of malachite green from aqueous solution, Ecol. Eng. 52 (2013) 19-27.

[8] M. Foroughi-dahr, H. Abolghasemi, M. Esmaieli, G. Nazari, B. Rasem, Experimental study on the adsorptive behavior of congo red in cationic surfactant-modified tea waste, Process Saf. Environ. Prot. 95 (2015) 226-236.

[9] A.A. Jalil, S. Triwahyono, M.R. Yaakob, Z.Z.A. Azmi, N. Sapawe, N.H.N Kamarudin, H.D. Setiabudi, N.F. Jaafar, S.M. Sidik, S.H. Adam, B.H. Hameed, Utilization of bivalve shell-treated Zea mays L. (maize) husk leaf as a low-cost biosorbent for enhanced adsorption of malachite green, Bioresour. Technol. 120 (2012) 218-224.

[10] H. Zhang, Y. Tang, X. Liu, Z. Ke, X. Su, D. Cai, X. Wang, Y. Liu, O. Huang, Z. Yu, Improved adsorptive capacity of pine wood decayed by fungi Poria cocos for removal of malachite green from aqueous solutions, Desalination 274 (2011) 97-104.

[11] S. Arellano-Cárdenas, S. López-Cortez, M. Cornejo-Mazón, J.C. MaresGutiérrez, Study of malachite green adsorption by organically modified clay using a batch method, Appl. Surf. Sci. 280 (2013) 74-78.

[12] E. Akar, A. Altinisik, Y. Seki, Using of activated carbon produced from spent tea leaves for the removal of malachite green from aqueous solution, Ecol. Eng. 52 (2013) 19-27.

[13] M.K. Dahri, M.R.R. Kooh, L.B.L. Lim, Water remediation using low cost adsorbent walnut shell for removal of malachite green: equilibrium, kinetics, thermodynamic and regeneration studies, J. Environ. Chem. Eng. 2 (2014) 1434-1444.

[14] A. Mohammadi, H. Daemi, M. Barikani, Fast removal of malachite green dye using novel superparamagnetic sodium alginate-coated $\mathrm{Fe}_{3} \mathrm{O}_{4}$ nanoparticles, Int. J. Biol. Macromol. 69 (2014) 447-455.

[15] P. Goyal, S. Srivastava, Characterization of novel Zea mays based biomaterial designed for toxic metals biosorption, J. Hazard. Mater. 172 (2009) 1206-1211.

[16] Y. Ren, Y. Yuan, B. Lai, Y. Zhou, J. Wang, Treatment of reverse osmosis (RO) concentrate by the combined $\mathrm{Fe} / \mathrm{Cu} / \mathrm{air}$ and Fenton process (1stFe/Cu/airFenton-2nd Fe/Cu/air), J. Hazard. Mater. 302 (2016) 36-44.

[17] L. Sun, H. Song, Q. Li, A. Li, Fe/Cu bimetallic catalysis for reductive degradation of nitrobenzene under oxic conditions, Chem. Eng. J. 283 (2016) 366-374.

[18] J. Trujillo-Reyes, V. Sánchez-Mendieta, A. Colín-Cruz, R. Morales-Luckie, Removal of indigo blue in aqueous solution using $\mathrm{Fe} / \mathrm{Cu}$ nanoparticles and $\mathrm{C}$ Fe-Cu nanoalloys composites, Water Air Soil Pollut. 207 (2010) 307-317.

[19] G. Garcia-Rosales, A. Colín-Cruz, Biosorption of lead by maize (Zea mays) stalk sponge, J. Environ. Manage. 91 (2010) 2079-2086.

[20] M. Petrović, T. Šoštarić, M. Stojanović, J. Milojković, M. Mihajlović, M. Stanojević, S. Stanković, Removal of $\mathrm{Pb}^{2+}$ ions by raw corn silk (Zea mays L.) as a novel biosorbent, J. Taiwan Inst. Chem. Eng. 58 (2016) 407-416.

[21] V.M. Vučurović, R.N. Razmovski, U.D. Miljić, V.S. Puškaš, Removal of cationic and anionic azo dyes from aqueous solutions by adsorption on maize stem tissue, J. Taiwan Inst. Chem. Eng. 45 (2014) 1700-1708.

[22] J. Trujillo-Reyes, V. Sánchez-Mendieta, M. Solache-Ríos, A. Colín-Cruz, Removal of remazol yellow from aqueous solution using Fe-Cu and $\mathrm{Fe}-\mathrm{Ni}$ nanoscale oxides and their carbonaceous composites, Environ. Technol. 33 (2012) 545-554. 
[23] K.R. Raj, A. Kardam, S. Srivastava, Development of polyethylenimine modified Zea mays as a high capacity biosorbent for the removal of As(III) and As(V) from aqueous system, Int. J. Miner. Process. 122 (2013) 66-70.

[24] S. Jayaram, S. Kapoor, S.M. Dharmesh, Pectic polysaccharide from corn (Zea mays L.) effectively inhibited multi-step mediated cancer cell growth and metastasis, Chem. Biol. Interact. 235 (2015) 63-75.

[25] J.B. Lambert, H.F. Shurvell, D.A. Lightner, R.G. Cooks, Organic Structural Spectroscopy, Prentice Hall Inc., USA, 1998.

[26] A. Reife, H. Freedman, Environmental Chemistry of Dyes and Pigments, John Wiley-Sons Inc., USA, 1996.

[27] W. Zou, H. Bai, S. Gao, Competitive adsorption of neutral red and $\mathrm{Cu}^{2+}$ onto pyrolytic char: isotherm and kinetic study, J. Chem. Eng. Data 57 (2012) 27922801.

[28] M. Kosmulski, The pH-dependent surface charging and points of zero charge $\mathrm{V}$. Update, J. Colloid Interface Sci. 353 (2011) 1-15.

[29] N. Sapawe, A.A. Jalil, S. Triwahyono, M.I.A. Shah, R. Jusoh, N.F.M. Salleh, B.H. Hameed, A.H. Karim, Cost-effective microwave rapid synthesis of zeolite NaA for removal of methylene blue, Chem. Eng. J. 229 (2013) 388-398.

[30] Y.S. Ho, Using of pseudo-second-order model in adsorption, Environ. Sci. Pollut. Res. 21 (2014) 7234-7235.

[31] E. Katsou, S. Malamis, M. Tzanoudaki, K.J. Haralambous, M. Loizidou, Regeneration of natural zeolite polluted by lead and zinc in wastewater treatment systems, J. Hazard. Mater. 189 (2011) 773-786.

[32] G.L. Dotto, L.A.A. Pinto, Adsorption of food dyes onto chitosan: optimization process and kinetic, Carbohydr. Polym. 84 (2011) 231-238.

[33] X. Peng, D. Huang, T. Odoom-Wubah, D. Fu, J. Huang, Q. Qin, Adsorption of anionic and cationic dyes on ferromagnetic ordered mesoporous carbon from aqueous solution: equilibrium, thermodynamic and kinetics, J. Colloid Interface Sci. 430 (2014) 272-282.

[34] Y.S. Ho, G. McKay, Sorption of dyes and copper ions onto biosorbents, Process Biochem. 38 (2003) 1047-1061

[35] S.J. Allen, G. McKay, K.Y.H. Khader, Intraparticle diffusion of a basic dye during adsorption onto sphagnum peat, Environ. Pollut. 56 (1989) 39-50.

[36] S. Wang, H. Li, L. Xu, Application of zeolite MCM-22 for basic dye removal from wastewater, J. Colloid Interface Sci. 295 (2006) 71-78.

[37] V. Vadivelan, K.V. Kumar, Equilibrium, kinetics, mechanism, and process design for the sorption of methylene blue onto rice husk, J. Colloid Interface Sci. 286 (2005) 90-100
[38] L. Leng, X. Yuan, G. Zeng, J. Shao, X. Chen, Z. Wu, H. Wang, X. Peng, Surface characterization of rice husk bio-char produced by liquefaction and application for cationic dye (malachite green) adsorption, Fuel 155 (2015) 7785.

[39] J. Torres-Perez, C. Gerente, Y. Andres, Conversion of agricultural residues into activated carbons for water purification: application to arsenate remova, J. Environ. Sci. Health Part A 47 (2012) 1173-1185.

[40] S. Márquez-Mendoza, M. Jiménez-Reyes, M. Solache-Ríos, E. Gutiérrez-Segura, Fluoride removal from aqueous solutions by a carbonaceous material from pyrolysis of sewage sludge, Water Air Soil Pollut. 223 (2012) 1959-1971.

[41] J. Torres-Pérez, M. Solache-Ríos, A. Colín-Cruz, Sorption and desorption of dye remazol yellow onto a mexican surfactant-modified clinoptilolite-rich tuff and a carbonaceous material from pyrolysis of sewage sludge, Water Air Soil Pollut. 187 (2008) 303-313.

[42] A. Witek-Krowiak, Analysis of influence of process conditions on kinetics of malachite green biosorption onto beech sawdust, Chem. Eng. J. 171 (2011) 976985.

[43] S. Chowdhury, S. Gupta, I. Kumar, Insight into adsorption equilibrium, kinetics and thermodynamics of malachite green onto clayey soil of Indian origin, Chem. Eng. J. 165 (2010) 874-882.

[44] Uma, S. Banerjee, Y.C. Sharma, Equilibrium and kinetic studies for removal of malachite green from aqueous solution by a low cost activated carbon, J. Ind. Eng. Chem. 19 (2013) 1099-1105.

[45] M.K. Dahri, M.R.R. Kooh, L.B.L. Lim, Water remediation using low cost adsorbent walnut shell for removal of malachite green: equilibrium, kinetics, thermodynamic and regeneration studies, J. Environ. Chem. Eng. 2 (2014) 1434-1444.

[46] H. Sadegh, R. Shahryari-Ghoshekandi, S. Agarwal, I. Tyagi, M. Asif, V.K. Gupta, Microwave-assisted removal of malachite green by carboxylate functionalized multi-walled carbon nanotubes: kinetics and equilibrium study, J. Mol. Liq. 206 (2015) 151-158.

[47] M.M. Lakouraj, R.S. Norouzian, S. Balo, Preparation and cationic dye adsorption of novel Fe304 supermagnetic/thiacalix[4] arene tetrasulfonate self-doped/ polyaniline nanocomposite: kinetics, isotherms, and thermodynamic study, J. Chem. Eng. Data 60 (2015) 2262-2272. 